\section{The Problem of Political Refugees}

ThE conference which opened at Evian on July 6 to discuss the plight of German and Austrian refugees was watched by a great body of opinion in Great Britain in which scientific workers are well represented. A letter welcoming the initiative of the Government of the United States in this matter which was sent to President Roosevelt on May 31 bore the signatures of many eminent men of science among other leaders of intellectual life. The letter urged that co-operation should make it possible to facilitate the transfer of refugees to those countries where their abilities can find most scope, and to provide funds to enable them to make a fresh start, and urged the British Government to play its part both administratively and financially in the support of the great traditions of liberty, tolerance and humanity which it has in common with the United States. A further letter to the chairman of the conference urged the importance of immediate, constructive and practical decisions alike on religious, humane and economic grounds if the great democracies are to retain their ancient traditions of freedom and the right of asylum.

WHILE none who have welcomed the conference are blind to the difficulties of the situation, even in regard to the admission of skilled professional men and women, still more in what may be called the police problem, the actual outcome of the conference was somewhat disappointing. The establishment of a permanent international committee of which, at its first meeting on August 3, when twenty-seven countries were represented, Lord Winterton was elected chairman, indicates that within a limited field efforts are being and will continue to be made to deal with this grave problem. The committee has prominent American representation, and since it is not a League of Nations organization, it should be easier for it to get in direct touch with all countries responsible for the main refugee problem. Moreover, the term 'refugee' has been extended to include persons who, though they may not yet actually have left Germany or Austria, feel obliged to quit those countries as soon as they can because of persecution due to political opinions, religious beliefs, or racial origin. While, too, the question of settlement is financial as well as territorial, the democracies have every reason, from their own self-interest as well as that of justice, to support the international committee in any steps it may initiate to bring pressure to bear on the expelling countries to release at least a proportion of the refugees' property to assist in their re-establishment elsewhere.

\section{Restoration of the Hurlers, Cornwall}

FURTHER work of restoration on the Hurlers, the stone circles near Minions, Cornwall, has been carried out during the past four weeks on behalf of the Office of Works under the supervision of Mr. R. Ralegh Radford, director of the British School of Archæology at Rome. These circles have been under the guardianship of, and owned by the Office of Works since 1935, when certain preliminary work of investigation and restoration of the central circle was undertaken. According to a statement made by Mr. Radford (The Times, August 12) the recent investigations have been directed to the examination of the northern circle. Four stones, additional to the previously known twelve, were found under modern tip heaps, and will be re-erected in the original sockets. Missing stones will be indicated, as in the central circle, by low stumps inserted in the original positions. The damage to the interior of the northern circle by mining test-holes and digging will be repaired by filling and levelling. A floor of granite fragments similar to that discovered in 1935, washed out of the surface soil, has been discovered covering the greater part of the interior of the circle. Its thickness is less than that of the previously discovered floor, this possibility, it is suggested, being due to it having remained in use for a longer period. An interesting feature now brought to light is a rough pavement between the northern and central circles, and running along their common axis. This pavement is about six feet wide but does not reach out to both circles. The suggestion of a ceremonial purpose will, no doubt, be elucidated when examination is completed before the close of the season's work. Flint implements, more numerous than in 1935, include several types characteristic of the early metal age, with some of an earlier period. Work will be continued in 1939, when it is hoped to restore the monument to its original appearance, so far as that is possible. It is also intended to explore the neighbouring barrow, in which the Rillaton gold cup, now in the British Museum, was found. This has never been explored scientifically.

\section{Roman Dorchester}

Further finds of interest are reported from Colliton Park and neighbouring land at Dorchester, where Roman buildings, it will be remembered, have been found on the site which is being prepared for the erection of a county hall. The Dorset Archæological Society, which has been responsible for supervising the work in the interests of archæology and for examining finds on the site, has recently made a cutting in Colliton Walk, adjoining the Park, which has brought to light part of the massive walls which once defended the Roman town. The walls, it is stated (The Times, August 12), were ten feet thick and of solid masonry. The ashlar facing has been removed, but the rubble core of flint and limestone, well mortared, still remains. The original wall was at least twenty feet high and was banked up internally by a large rampart, on the top of which was a walk for the sentries. It is hoped that further investigation may bring to light the foundations of the towers which were a feature of such fortifications. The walls at this point were destroyed a hundred years ago, when the walks were laid out; but enough has now been found to show the nature of the original construction. In the Park itself, where the site is now in the hands of the contractors, some further remains have been found. Among these is a water conduit, one of the open distributing channels of the Roman system of water supply. It is at the bottom 
of a V-shaped cutting ten feet deep. The channel itself is four feet wide, with a bottom of red earthenware tiles. No conduit of this type had previously been found in this part of Roman Britain. It appears to have gone out of use in the second century A.D. The foundations of the three-roomed Roman building have now been cleared, and show the remarkable and unusually wide doorway, which is seven feet across.

\section{Prehistoric Civilization of Northern France}

THE party of archæologists deputed by the Society of Antiquaries of London to carry out archæological investigations in northern France is now at work in Brittany and western Normandy under the direction of Dr. R. E. Mortimer Wheeler. The expedition has been undertaken with the good will of, and under a permit from the French authorities, in accordance with an agreement into which the Society of Antiquaries entered with them last year. This investigation will constitute the major undertaking for the time being of the Society in archæological research in the field, taking the place of the excavation of Maiden Castle, Dorchester, upon which it was engaged, with Dr. Wheeler as its director, for some years. The purpose of the investigation in France is to search for evidence of the cross-channel origin of the eivilization of southwestern Britain in the later prehistoric period, and more especially of the fortified towns which appear there suddenly in a state of mature development, but of which the source is uncertain. This is a department of investigation in France which French archæologists have left virtually untouched. The programme of the investigators is in the first place to map the distribution of pre-Roman earthworks of the Maiden Castle type in north-western France, and secondly to ascertain by trial excavation on selected sites what cultures went to make up these Continental works. The first centre which has been chosen for excavation is Huelgoat, a well-known site in the pine forest about twenty miles south of Morlaix, where a camp nearly a mile in length is under examination. It is seen to have been built in the first century B.c. on the eve of the Roman conquest of northern France. The rampart, fifteen feet high, is faced with stone and bonded with lacing timbers. The ditch is in part cut out of the granite rock. The search for other sites has progressed so far as to show that the great Wessex fortified sites did not originate in Finistère, though certain smaller fortified enclosures in that department can be paralleled in Cornwall. Investigation will shortly move farther east to a large camp in the neighbourhood of Avranches.

\section{Fungus Diseases of Animals}

A NEW journal devoted to the fungus diseases of man and other animals has recently commenced publication (Mycopathologia, Den Haag, Dr. W. Junk, 18 Dutch florins per volume, 1, Fasc. 1, 80 pp. May 1938). The publication is international; it is edited in Italy and printed in Holland; the United States provides the first number with several authors, whilst the list of collaborators is long and geo- graphically extensive. R. Ciferri, director of the Botanical Laboratory of the Faculty of Agriculture in the University of Florence, and P. Redaelli, director of the Institute of Pathological Anatomy in the University of Padua, are the joint editors. They contribute the first paper on "A New Hypothesis on the Nature of Blastocystis". This organism shows more affinities with certain algæ than with sporogenous yeasts, and the general biologist will welcome the discovery of a further link between fungi and algæ. Classification of fungi belonging to the genus Actinomyces is considered by E. Baldacci of Padua. The rest of the papers in the present number demonstrate the wide scope and outlook of the journal. The papers are all scientific contributions to a littleknown section of mycology, and a "Bibliographia Mycopathologia" of references to work published in 1937 adds further utility. The production is excellent, both of type and plates, and the volume should supply a particularly welcome quota of knowledge in Great Britain, where fungal diseases of man are apparently not common enough to provoke research on a large scale.

\section{Advances in Printing Telegraph Technique}

IT is shown in a paper by A. E. Thompson, published in Electrical Communication of April, that at no period in the history of the telegraph has there been such revolutionary improvements in methods and equipment or such rapid development and expansion in its service to the community as during the last ten years. The progress was initiated by the introduction of teleprinter systems, which by providing instruments requiring no telegraphic skill on the part of the operators have completely changed the outlook of telegraphy and greatly stimulated development in all its branches. Teleprinters are superseding all the older types of machine telegraphic apparatus. Even hand Morse working, which has been the backbone of telegraphy for more than a century, has now been abandoned in the British telegraph service, the bulk of the traffic being handled by Creed teleprinters. Similar developments are taking place in other countries. A description is given of the new Creed No. 10 tape teleprinter. The improvements achieved are trustworthy service at 85 words per minute, reduced costs, quiet operation and reduced size. Maintenance costs have been reduced by evolving mechanisms with a breakdown speed exceeding 100 words per minute. The printer operates continuously for 300 hours without requiring lubrication. Ballbearings and oil-impregnated bearings as well as sliding surfaces lubricated by means of oil reservoirs are used. This machine can be used by telegraph administrations and private companies as well as by high-speed news and ticker services.

\section{History of Maize-Breeding}

IN a recent lecture given at the Michigan State College, Mr. Henry A. Wallace, the United States Secretary of Agriculture, traced the history of maize or corn breeding and pointed out that up to 1890 the farmers of the corn-belt had not been superior to their Indian predecessors as corn breeders, the chief 